\title{
BOARDS OF DIRECTORS AS AN ENDOGENOUSLY DETERMINED INSTITUTION: A SURVEY OF THE ECONOMIC LITERATURE
}

\author{
Benjamin E. Hermalin \\ Michael S. Weisbach \\ Working Paper 8161 \\ http://www.nber.org/papers/w8161 \\ NATIONAL BUREAU OF ECONOMIC RESEARCH \\ 1050 Massachusetts Avenue \\ Cambridge, MA 02138 \\ March 2001
}

The NSF (Grant SBR-9616675) and the Willis H. Booth Chair in Banking \& Finance provided financial support. We thank Bernie Black, Jim Brickley, Murillo Campello, Ben Esty, Kevin Hallock, Jinyu He, Anju Seth, and Anil Shivdasani for helpful comments on an earlier draft, and Hamid Mehran for encouraging us to write this paper. The authors can be reached at hermalin@haas.berkeley.edu or weisbach@uiuc.edu. The views expressed herein are those of the authors and not necessarily those of the National Bureau of Economic Research.

(C) 2001 by Benjamin E. Hermalin and Michael S. Weisbach. All rights reserved. Short sections of text, not to exceed two paragraphs, may be quoted without explicit permission provided that full credit, including $($ ) notice, is given to the source. 
Boards of Directors as an Endogenously Determined Institution:

A Survey of the Economic Literature

Benjamin E. Hermalin and Michael S. Weisbach

NBER Working Paper No. 8161

March 2001

JEL No. G3, L2

\begin{abstract}
$\underline{\text { ABSTRACT }}$
This paper surveys the economic literature on boards of directors. Although a legal requirement for many organizations, boards are also an endogenously determined governance mechanism for addressing agency problems inherent to many organizations. Formal theory on boards of directors has been quite limited to this point. Most empirical work on boards has been aimed at answering one of three questions:

1) How are board characteristics such as composition or size related to profitability?

2) How do board characteristics affect the observable actions of the board?

3) What factors affect the makeup of boards and how they evolve over time?

The primary findings from the empirical literature on boards are: Board composition is not related to corporate performance, while board size has a negative relation to corporate performance. Both board composition and size are correlated with the board's decisions regarding CEO replacement, acquisitions, poison pills, and executive compensation. Finally, boards appear to evolve over time as a function of the bargaining power of the CEO relative to the existing directors. Firm performance, CEO turnover, and changes in ownership structure appear to be important factors affecting changes to boards.
\end{abstract}

Benjamin E. Hermalin University of California at Berkeley

hermalin@haas.berkeley.edu
Michael S. Weisbach University of Illinois and NBER

weisbach@uiuc.edu 


\section{Introduction}

Most organizations are governed by a board of directors. Having a board is one of the legal requirements for incorporation, and many non-incorporated entities have a governing board of some sort (e.g., a state university's board of regents). Why do boards exist? What do they do? Can they be "improved"? These questions get at the heart of governance, and to a certain extent, management. As such, they have become a source of much research.

This paper surveys the research on boards of directors in the economics and finance literatures. Boards of directors are an economic institution that, in theory, helps to solve the agency problems inherent in managing an organization. Although boards satisfy numerous regulatory requirements, their economic function is determined by the organizational problems they help to address. Yet, formal economic theorizing about boards has been quite limited. For example, the characteristics of agency problems that could yield boards as the equilibrium solution have not yet been specified. Similarly, the conditions under which regulations of boards will lead to improvements are unknown.

Despite the absence of formal theory, we have a strong intuitive sense of the problems facing boards. The major conflict within the boardroom is between the CEO and the directors. The CEO has incentives to "capture" the board, so as to ensure that he can keep his job and increase his the other benefits he derives from being CEO. Directors have incentives to maintain their independence, monitor the CEO, and to replace him if his performance is poor.

To some extent, the vacuum in formal theory has been filled by empirical work on boards. The "cost," of this approach, however, is that little of the empirical work on boards has been motivated by formal theory. Rather, it has sought to answer one of three questions:

1) How do board characteristics such as composition or size affect profitability? 
2) How do board characteristics affect the observable actions of the board?

3) What factors affect the makeup of boards and how do they evolve over time?

A key issue in this empirical work is how to proxy for the board's degree of independence from the CEO. Much of this work starts from the sometimes implicit assumption that observable board characteristics, such as size or composition, are related to the level of board independence.

A number of empirical regularities have been established by the empirical literature.

First, board composition, as measured by the insider/outsider ratio, ${ }^{1}$ is not correlated with firm performance. However, the number of directors on a firm's board is negatively related to the firm's financial performance. Second, board actions do appear to be related to board characteristics. Firms with higher fractions of outside directors and smaller boards tend to make better decisions concerning, acquisitions, poison pills, executive compensation, and CEO replacement. Finally, boards appear to evolve over time depending on the bargaining position of the CEO relative to that of the existing directors. Firm performance, CEO turnover, and changes in ownership structure appear to be important factors affecting changes to boards.

Two important issues complicate empirical work on boards of directors, as well as most other empirical work on governance. First, almost all the variables of interest are endogenous. The usual problems of joint endogeneity, thus, plague these studies. For instance, firm performance is both a result of the actions of previous directors and, itself, a factor that potentially influences the choice of subsequent directors. Studies of boards often neglect this issue and, so, obtain results that are hard to interpret.

\footnotetext{
${ }^{1}$ Most directors can be classified as inside directors or outside directors. Inside directors are employees or former employees of the firm. They generally are not thought to be independent of the CEO, since the success of their careers is often tied to the CEO's. Outside directors are not employees of the firm and usually do not have any business ties to the firm aside from their directorship. Outside directors are typically CEOs from other firms or prominent individuals in other fields. Finally, about $10 \%$ of directors fall into neither category; often these are attorneys or businesspeople that have a longstanding relationship with the firm. These directors are usually referred to as "affiliated" or "gray" directors.
} 
Second, many empirical results on governance can be interpreted as either equilibrium or out-of-equilibrium phenomena. While it is generally difficult to distinguish between the two interpretations in a given study, they often have drastically different implications for policy. For example, one of the most consistent empirical relations regarding boards of directors is that board size is negatively related to firm profitability. The out-of-equilibrium interpretation of this finding says that limits on board size should be encouraged, or perhaps even mandated. In contrast, the equilibrium interpretation of this result implies that some other factor is causing both board size and profitability, so that such regulation would be at best useless, and possibly counterproductive. Both endogeneity considerations and the equilibrium nature of the results should be carefully considered when evaluating any study of boards or any other aspect of corporate governance.

Despite these issues, much has been learned about boards of directors in public corporations in the past 15 years. Yet, there is still much work to be done. This literature has proceeded in the opposite direction from the scientific method archetype; the empirical literature on boards in public corporations is fairly well developed, while theory is still in its infancy. It is likely that subsequent developments in theory will lead to more sophisticated empirical tests of particular models. In addition, the governance of organizations other than for-profit corporations is a relatively unexplored area. Both theoretical and empirical work aimed at understanding these organizations is likely to bear fruit in the near future.

Several caveats are in order. First, in surveying the literature on boards of directors, we emphasize the parts we know best. We have tried our best to be fair to all authors, but nonetheless plead guilty to spending a disproportionate amount of space on our own work. We apologize if we have neglected your favorite paper or misinterpreted it. Second, boards of 
directors are an important topic of research in many areas, not just economics. Important research has been conducted from both managerial and legal perspectives. We have omitted discussion of these literatures entirely. Kosnik (1990), Zajac and Westphal (1994), and Rediker and Seth (1995) provide good introductions to the management literature on boards. From the legal literature, one particularly noteworthy study is Roe (1994). Finally, boards of directors are only one element of corporate governance systems. See Shleifer and Vishny (1997) for a broader survey of corporate governance.

\section{Conceptual Issues}

As with so much of economics, Adam Smith (1776) appears to be the first economist to address boards of directors:

"The directors of [joint stock] companies, however, being the managers rather of other people's money than of their won, it cannot well be expected, that they should watch over it with the same anxious vigilance [as owners] ... Negligence and profusion, therefore, must always prevail, more of less, in the management of the affairs of such a company" (p. 700).

One hundred fifty-six years later, Berle and Means (1932) took a largely similar view:

"... control will tend to be in the hands of those who select the proxy committee and by whom, the election of directors for ensuing period will be made. Since the proxy committee is appointed by the existing management, the latter can virtually dictate their own successors." (p. 87)

Both quotes point out the agency issues that have typically caught economists' eyes. Until recently, however, economic theory was insufficiently developed to analyze such agency problems. But a "problem" these issues clearly seemed to be, and not only to economists. Much of the regulation of boards since Adam Smith's day has been driven by a desire to solve this "problem." Even today, the press regularly chides boards for being insufficiently vigilant guardians of other people's money and being too much in management's hands. Similarly, we 
still hear calls for "reforms." For instance, the American Law Institute (1982), Lorsch and Lipton (1992), and Jensen (1993) have each made proposals that, if adopted, would impose restrictions on the workings of boards.

Yet, one doesn't have to hold a Chicago Ph.D. to ask, "if boards are so bad, why hasn't the market caused them to improve or, even, replaced the corporate form with less-problematic forms of organization?" Or put differently, pointing out that an institution is not first-best efficient is not the same as demonstrating that outside regulation is needed. A reasonable possibility is that boards are the second-best efficient solution to the various agency problems confronting any organization with such a potentially large divergence in interests among its members. As a matter of economic theory, the conditions under which we could expect such regulation to be welfare enhancing are rather limited (see, e.g., Hermalin and Katz, 1993).

Perhaps, then, before we rush to regulate boards, we should step back and ask to what problems are boards the solution? That is, why are there boards?

\subsection{Why are there boards of directors?}

One potential answer to the question of why boards exist is that they are simply a product of regulation. Between state incorporation laws and the stock exchange governance requirements, most firms are required to have a board meeting a multitude of requirements: It must have at least so many members, it must meet with at least some specified regularity, it may need to have various committees, and some fraction of the directors may be obligated to have some nominal independence from management.

Yet, this can't be the entire story. Governing boards are prevalent all over the world, in a variety of for-profit and nonprofit organizations; more importantly, the existence of governing boards predates these regulations. Furthermore, if they existed simply to satisfy regulatory 
requirements, they would represent deadweight costs on firms, which subsequent lobbying presumably would have been eliminated, at least somewhere in the world. In fact, the available evidence suggests the contrary: Were boards a deadweight cost to the firm, then we should expect them to all be at minimum size as fixed by regulation. Yet, in practice, boards are generally much larger than required by law.

Given their prevalence over time, across boundaries, and in different organizational forms, there must be an explanation for boards other than a regulatory-based one. A more plausible hypothesis is that boards are a market solution to an organizational design problem, an endogenously determined institution that helps to ameliorate the agency problems that plague any large organization. Whatever their virtues or problems, boards of directors are part of the market solution to the contracting problems inside of most organizations. We believe that viewing boards of directors from this perspective is the most useful way to study the way they are structured and function.

Our point of departure is therefore that a board of directors is the equilibrium solution (albeit possibly second best) to some agency problems confronting the firm. But what agency problems? And why boards as the solution?

The canonical agency problem is that between a firm's owners, its shareholders, who are generally seen as unable to control management directly, and management, who, as Smith feared, tend to be insufficiently vigilant or trustworthy when it comes to other people's property. One solution to this problem is to provide management with strong incentives contractually. But this begs the question of who provides these incentives and who ensures that the incentive contracts are structured optimally? In most large corporations the shareholders are too diffuse, 
rationally plagued by the free-rider problem, and, for the same reason, too uninformed to set managers' compensation.

This problem, and the underlying direct control problem as well, could be alleviated in situations in which a large outside shareholder has sufficient incentive herself to tackle them. Many models have, consequently, explored the role for a large outside shareholder (see Shleifer and Vishny, 1986, for example). While there are certainly instances in which large shareholders play an important governance role, this is also certainly not a universal solution. ${ }^{2}$ Moreover, the stage on which a large shareholder plays this role is often the board itself; that is, her power works through her position on the board or her control of some number of directors. Ultimately, the theoretical literature on boards will derive the board as part of the equilibrium solution to the contracting problem between diffuse shareholders and management.

One idea for why boards emerged is that the directors' mutual monitoring was critical for inducing shareholders to trust the directors with their money. For example, suppose that there were $S$ of the shareholders' dollars that potentially could be stolen, and that the penalty to a director (monetarily, criminally, or to reputation) was $p$, with $S>p>0$. In addition, suppose that any director can costlessly prevent such theft. Then $N$ directors will "steal" if $S / N>p$. Clearly, there exists an $N>1$ such that stealing is a strictly dominated strategy. In a similar vein, Meissner (2000) has explored the issue of how bank directors in early $19^{\text {th }}$-century New England limited self-dealing. His argument is that the total amount of side payments a given director would have to make to his fellow directors to bribe them to approve a bad loan on his behalf would ultimately prove prohibitive vis-à-vis the gains the given director could expect. To be

\footnotetext{
${ }^{2}$ As institutions' holdings have grown, they have played a much more active role monitoring management governance in recent years. See Karpoff (1998) or Carleton et. al (1998) for discussion of shareholder activism and recent evidence on large institutional shareholders' efforts to change corporate governance.
} 
sure, these ideas are neither complete models, nor do they necessarily explain the continued existence of boards today.

\subsection{How are Boards Structured and What do they do?}

Even without a complete theory of why there are boards, we can still explore how boards are structured and what they do. Boards are generally made up of a mixture of insiders and outsiders; how is this mixture determined and what are the incentives of different directors? Conditional on composition, do boards function as they should; that is, is their performance optimal (at least in a second-best sense)?

One modeling approach is to see the board as the "principal" to management's "agent" in a classic principal-agent framework. Although such principal-agent modeling provides many insights, it is not particularly useful for explaining board-specific phenomena: For example, why the ratio of insiders to outsiders matters or changes; or why management seems to have such influence on the selection of directors?

Outside directors are often thought to play the monitoring role inside boards. Yet, their incentives are not clear. Fama (1980) and Fama and Jensen (1983) emphasize the fact that they have incentives to build reputations as expert monitors. ${ }^{3}$ On the other hand, a reputation as a director who does not make trouble for CEOs is potentially valuable to a director as well. Moreover, as Holmstrom (1999) observes, wanting to be seen as doing the right thing and doing the right thing are not always the same. The set of incentives facing the outside directors that result from these divergent forces is an important underlying factor in many of the studies surveyed below.

\footnotetext{
${ }^{3}$ See Kaplan and Reishus (1990) and Farrell and Whidbee (2000) for evidence on the reputation argument.
} 
Hermalin and Weisbach (1998) offer a more board-specific model. They focus on one of the primary board tasks, the hiring and firing of management. In their model, the board must decide whether to keep a CEO or to replace him. The firm's performance provides a signal of the CEO's ability, and the board may, if it chooses, obtain an additional, costly signal. The board's inclination is, in turn, a function of its independence from the CEO. A board's independence depends on a bargaining game between the board and the CEO: The CEO prefers a less independent board while the board prefers to maintain its independence. When the CEO has bargaining power-specifically when the CEO has demonstrated that he's a "rare commodity" by performing exceptionally well—the board's independence declines. Alternatively, poor firm performance reduces a CEO's perceived ability relative to that of a potential replacement, increasing the likelihood that the board will replace him. This model derives a number of predictions about the dynamics of the $\mathrm{CEO}$ and board's relationship. In particular, it predicts:

1. A CEO who performs poorly is more likely to be replaced than one who performs well.

2. CEO turnover is more sensitive to performance when the board is more independent.

3. The probability of independent directors being added to the board rises following poor firm performance.

4. Board independence declines over the course of a CEO's tenure.

5. Accounting measures of performance are better predictors of management turnover than stock-price performance.

6. There should be long-term persistence in corporate governance.

7. The stock-price reaction to management changes should be negative if the CEO is fired based on private information, but positive if the manager is fired on the basis of public information. 
8. A CEO's salary should be insensitive to past performance at relatively low levels of past performance, but sensitive at relatively high levels of past performance.

There is strong empirical evidence to support the first five of these: For instance, Weisbach's (1988) results are consistent with the first two predictions; Bhagat and Black (2000) and Hermalin and Weisbach (1988) find results that are consistent with the third and fourth predictions; and, likewise, the fifth prediction is supported by numerous studies, of which Weisbach (1988) is one example. To the best of our knowledge, the last three predictions have not been empirically tested.

There are other stylized facts about boards that do not, as of yet, arise as equilibria from formal models. ${ }^{4}$ Why, for instance, are directors reluctant to challenge the CEO (see, e.g., Mace, 1986)? Why does board size appear to affect performance (Yermack, 1996)? Why are boards an effective way of supplying information to management, as some suggest (e.g., Mace, 1986)? Why are boards an effective way to groom future CEOs (Vancil, 1987)? As the trend towards careful modeling of economic institutions continues, boards will prove fertile ground for work.

\section{Empirical Work on Boards of Directors}

In contrast to the relative paucity of theoretical work on boards, there is a large empirical literature on the subject. Excluding case-based studies (e.g., Mace, 1986 and Vancil, 1987), this research can be broadly characterized as estimating one or more of the equations in the system:

$$
\begin{aligned}
& a_{\mathrm{t}+\mathrm{s}}=\phi c_{\mathrm{t}}+\varepsilon_{\mathrm{t}} \\
& p_{\mathrm{t}+\mathrm{s}}=\beta a_{\mathrm{t}}+\eta_{\mathrm{t}} \\
& c_{\mathrm{t}+\mathrm{s}}=\mu p_{\mathrm{t}}+\xi_{\mathrm{t}}
\end{aligned}
$$


where $c$ denotes a characteristic or characteristics of the board (e.g., composition or size), $a$ denotes an action (e.g., dismissal of the CEO), $p$ denotes firm performance (e.g., profits), $t$ indexes time (s $\geq 0), \phi, \beta$, and $\mu$ are parameters (more accurately function operators) to be estimated, and $\varepsilon, \eta$, and $\xi$ denote the rest of the specification (plus errors). Typically, the entire system is not estimated simultaneously, so the joint endogeneity is handled using lags (i.e., $s>0$ ) on the equation of interest. Observe, from the first two equations, that it is possible to directly study the relationship between board characteristics and firm performance; that is,

$$
p_{\mathrm{t}+\mathrm{s}}=\beta\left(\phi c_{\mathrm{t}}+\varepsilon_{\mathrm{t}}\right)+\eta_{\mathrm{t}}
$$

A number of studies have directly estimated this equation. Indeed, such studies are more prevalent than studies of the component equations (this is especially true for the "middle" equation of performance as a function of board actions). ${ }^{5}$

\subsection{The Board's Influence on Corporate Performance}

We begin by reviewing the literature that has estimated the "composite" equation, (4). Two board characteristics have been used as the independent variable: board composition (typically measured by the proportion of outside — non-management — directors on the board) and board size.

\subsubsection{Board Composition and Corporate Performance}

Probably the most widely discussed question regarding boards is "Does having more outside directors increase corporate performance?" A number of papers have addressed this question, using several methods. The first method has been to examine contemporaneous correlations between accounting measures of performance and the proportion of outside directors on the

\footnotetext{
${ }^{4}$ Some other models relating to boards of directors are Almazan and Suarez (2000), Hirshleifer and Thakor (1994) and Warther (1998).
} 
board. MacAvoy et. al. (1983), Baysinger and Butler (1985), Hermalin and Weisbach (1991), Mehran (1995), Klein (1998), and Bhagat and Black (2000) all report insignificant relations between accounting performance measures and the fraction of outside directors on the board. A second approach, suggested by the work of Morck et. al (1988), is to use Tobin's $q$ as a performance measure, the idea being that it reflects the "value added" of intangible factors such as governance. Hermalin and Weisbach (1991) and Bhagat and Black (2000) use this approach and find, as with accounting performance measures, there is no noticeable relation between the proportion of outside directors and $q$. Finally, Bhagat and Black (2000) examine the effect of board composition on long-term stock market and accounting performance. Once again, they do not find any relation between board composition and firm performance. Overall, there is little to suggest that board composition has any cross-sectional relation with firm performance. ${ }^{6}$

An important issue to consider when evaluating these studies is the endogeneity of board composition. Hermalin and Weisbach (1998) suggest that poor performance leads to increases in board independence. In a cross-section, this effect is likely to make firms with independent directors look worse, because this effect leads to more independent directors on firms with historically poor performance. Both Hermalin and Weisbach (1991) and Bhagat and Black (2000) have attempted to correct for this effect using simultaneous equation methods. In particular, these papers lagged performance as an instrument for current performance. Still, even correcting for endogeneity in this manner, there does not appear to be an empirical relation between board composition and firm performance.

\footnotetext{
${ }^{5}$ Most of this literature focuses on the monitoring of boards of directors. Of course, boards do other things as well inside of firms. For an interesting discussion of the political role played by some directors, see Agrawal and Knoeber (2001).

${ }^{6}$ One exception is Baysinger and Butler (1985), who finds that the 1970 proportion of independent directors is positively related to 1980 return on equity. However, as Bhagat and Black (1999) emphasize, these authors use only a single performance measure and 10 years seems like an implausibly long time during which to observe performance improvements from something like board composition.
} 
The poor results in estimating the "composite equation" are not surprising-errors from both underlying equations are present, so the signal-to-noise ratio is low. In particular, firm performance is a function of so many different factors that it is difficult to imagine that the effect of occasional board meetings, etc., would be detectable (especially as the case-study literatureMace, 1986, Lorsch and MacIver, 1989—suggest that the vast majority of these meetings result in no significant actions).

A somewhat more successful approach has been to measure the impact on firm value of changes in board composition. Rosenstein and Wyatt (1990) examine the stock price reaction on the day of the announcement that outside directors will be added to the board. They find that, on average, there is a statistically significant $0.2 \%$ increase in stock prices in reaction to the announcement of these appointments.

In many ways, the Rosenstein and Wyatt approach is a cleaner test of the relationship between board composition and ultimate value than the other studies considered above- the Rosenstein and Wyatt approach controls for all firm-specific effects and tests directly for the desired effect. Controlling for firm-specific effects is critical because-as Hermalin (1994) predicts and Kole (1997) and Hermalin \& Wallace (1998) confirm-there is no reason to imagine that a specific board composition (e.g., percentage of outsiders) is optimal for all firms. Hence, the impact of board composition on performance could be difficult to identify crosssectionally.

On the other hand, there is a potential drawback to the Rosenstein and Wyatt approach. Suppose firms change their board structure only to improve their value. Then all change announcements, to the extent that they are unexpected, should cause a positive change in the stock price. If this is true, then the Rosenstein and Wyatt results tell us nothing about the value of 
outsiders per se. On the other hand, if only the addition of outsiders increased firm value, while other changes were neutral or lowered firm value, then we need to ask why this is allowed to happen and why firms do not continually add outsiders to boost value. Rosenstein and Wyatt address some of these concerns in their follow-up article (Rosenstein and Wyatt, 1997). Overall, they find no definitive effect of adding an insider to the board. In some specifications, however, they find that adding an insider increases the stock price. Hence, the original Rosenstein and Wyatt effect could, as we've suggested, simply reflect value-increase associated with the change, rather than anything in particular about outsiders.

These questions highlight the difficulties interpreting the results from much of the empirical literature on boards. Specifically, either these papers are estimating equilibrium phenomena or they are estimating an out-of-equilibrium situation. If the equilibrium interpretation is correct, it is hard to explain how certain actions could consistently increase firm value. In contrast, if one believes the out-of-equilibrium interpretation, one must first address the issue of how the firms arrived at this out-of-equilibrium situation.

\subsubsection{Board Size and Corporate Performance}

In addition to board composition, Jensen (1993) and Lipton and Lorsch (1992) suggest that large boards can be less effective than small boards. The idea is that when boards get to be too big, agency problems increase and the board becomes more symbolic and less a part of the management process. Yermack (1996) tests this view empirically and finds support for it. He examines the relation between Tobin's $q$ and board size on a sample of large U.S. corporations, controlling for other variables that are likely to affect $q$. Yermack's results suggest that there is a significant negative relation between board size and $q$. Confirming the Yermack finding, Eisenberg et. al. (1998) document that a similar pattern holds on a sample of small and midsize 
Finnish firms. The data, thus, appear to yield a fairly clear picture: Board size and firm value are negatively correlated.

Another measure of the importance of board size is how participants in the marketplace view it. In a novel approach, Gertner and Kaplan (1996) examine the boards of a sample of reverse leveraged buyouts. Their idea is that these firms are more likely than ongoing public firms to choose a "value-maximizing" board. Gertner and Kaplan find that, in this sample, boards tend to be smaller than in otherwise similar firms. Wu (2000) considers the evolution of board size over the 1991-1995 period. She finds that board size decreased on average over this period and that the decrease can be, at least partially, explained by pressure from active investors such as CALPERs. Market participants seem to think that small boards do a better job monitoring management than do large boards.

Although striking, these results nevertheless raise some questions: Why, if they are destructive to firm value, do we see large boards? Perhaps large boards are uniformly bad because size exacerbates some free-riding problems among directors vis-à-vis the monitoring of management. But then why does the market permit them to exist; why hasn't economic Darwinism eliminated this unfit organizational form? These questions raise the issue of whether an equilibrium phenomenon or an out-of-equilibrium situation is being estimated. Sorting out the appropriate interpretation for these results on board size and corporate performance seems like a particularly useful topic of future research.

\subsection{Boards of Directors and Particular Tasks}

In addition to studying the relation between board characteristics and firm performance, a number of studies have examined how boards accomplish some of the responsibilities commonly assigned to directors. In terms of our heuristic system of equations, these studies can be thought 
of as estimates of actions, $a$, as a function of characteristics, $c$. This approach has several advantages relative to looking at the effect of boards on overall firm value. First, since there are so many factors affecting performance, this approach is potentially more powerful, because it is less prone to unobservable factors' contaminating the statistical relation. Second, when examining particular tasks of directors, it is less likely that the endogeneity of board composition will affect the results. In general, this type of test is much cleaner than the tests relating composition to firm performance.

\subsubsection{CEO Turnover}

The most commonly discussed responsibility of the board is to choose and to monitor the firm's CEO (see Mace, 1986, for example). Indeed, rather than make day-to-day decisions, boards appear to play a crucial role in picking the firm's CEO and to view their primary responsibility as monitoring and potentially replacing him. One way, therefore, to evaluate the board's effectiveness is by looking at the quality of these decisions.

A large number of papers have documented that there is a positive relation between CEO turnover and poor performance in large corporations, as well as other types of organizations. ${ }^{7}$ In addition, Denis and Denis (1995) document that firm performance generally improves following a CEO turnover, especially forced turnover. The standard interpretation of this relation is that it measures the board's monitoring; when performance is worse, the board is more likely to find the current CEO unacceptable and to make a change.

An important issue in all of these studies is distinguishing voluntary from involuntary turnovers, which is usually difficult and, in some cases, impossible. Studies take different approaches to dealing with the issues of voluntary turnover-some papers ignore the issue, some 
exclude observations pertaining to CEOs at retirement age, and some make a detailed effort to distinguish forced departures from voluntary turnover. Nonetheless, voluntary turnovers are unlikely to be related to performance and the negative relation between performance and CEO turnover is extremely robust across samples. Therefore, the measured negative relation between turnover and performance probably reflects boards firing CEOs (i.e., the difficulty in distinguishing the two types of turnover merely adds noise to the dependent variable and, thus, is irrelevant beyond its impact on the standard errors).

Simply documenting a relation between poor performance and an increased probability of a CEO turnover, although suggestive of board monitoring, is nonetheless far from conclusive. After all, a sense of failure or pressure from outside shareholders could explain this relationship. To better identify the role played by the board, Weisbach (1988) interacts board composition and firm performance in a CEO turnover equation. His results indicate that when boards are dominated by outside directors, CEO turnover is more sensitive to firm performance than it is in firms with insider-dominated boards. This result holds when firm performance is measured either with market-adjusted stock returns or with an accounting measure of performance. This result is consistent with the view that outsider-dominated boards-those a priori likely to be independent of management — are responding to corporate performance when they make CEOretention decisions. In contrast, turnover in insider-dominated boards is not performance-driven, suggesting that insider dominated boards make turnover decisions for reasons unrelated to corporate performance.

The most plausible interpretation of this finding is that boards controlled by outside directors do a better job of monitoring the CEO than do boards controlled by inside directors.

\footnotetext{
${ }^{7}$ Among them, Coughlan and Schmidt (1985), Warner, Watts, and Wruck (1988), Weisbach (1988), Jensen and Murphy (1990), Barro and Barro (1990), Blackwell et al. (1994), Kaplan (1994), Brickley and Van Horn (2000),
} 
However, a possible alternative explanation is that inside directors make their turnover decisions on the basis of inside information. Since by definition, this information is not known to market participants, it will not be incorporated into the stock price. This interpretation implies that even though insider-dominated boards are responding to performance, the performance they are responding to is not measurable by an outside observer. A point against the inside-information explanation is that such information is likely to be correlated with measurable performance (at least ex post), suggesting that CEO turnover in insider-dominated boards would still be somewhat responsive to measured performance.

In addition, there is a theoretical reason to favor the monitoring explanation over the asymmetric information explanation. Inside directors' careers tend to be tied to the CEO's, which gives them incentives to advance the CEO's career regardless of the stock price. Moreover, any potential inside information inside directors use to justify the firing has to be negative about the CEO without being negative about them, since otherwise shareholders would likely respond to the CEO's dismissal by demanding a clean sweep of top management. Consistent with this point is evidence from Borokhovich et al. (1996) and Huson et al. (2000), who find outsider-dominated boards are more likely than insider-dominated boards to replace a CEO with someone from outside the firm. ${ }^{8}$

Yermack (1996) and Wu (2000) perform a similar analysis of CEO turnover, measuring the impact of board size on the relation between CEO turnover and firm performance. These papers estimate similar equations to Weisbach (1988), except that they substitute an interaction

Eldenburg et al. (2000), and Huson et al.(2000).

${ }^{8} \mathrm{~A}$ third explanation is that board composition is a function of the quality of executives just below the CEO. When there are high-quality inside alternatives to the CEO, these executives will be more likely to be directors, leading to more inside directors on average. In addition, they will tend to replace the CEO for reasons that might not be related to publicly-available measures of performance and it will be more likely in these firms that the replacement CEO will be an insider, consistent with Borokhovich et al. and Huson et al. 
of the log of board size with firm performance for Weisbach's interaction of board composition with firm performance. Both Yermack and $\mathrm{Wu}$ find a positive and significant coefficient on this interaction term, which indicates that firms with smaller boards have a stronger relation between firm performance and CEO turnover than do firms with larger boards. This finding is consistent with the view that smaller boards are more effective overseers of the CEO than larger boards. In particular, in response to poor performance, they may not be paralyzed by free-riding or otherwise plagued with inertia the way larger boards are. It is also possible that smaller boards are more effective at obtaining inside information that ultimately will be reflected in measured performance.

Perry (2000) breaks down the cross-sectional relation between CEO turnover and firm performance by whether the outside directors are paid using incentives. He finds that the relation between CEO turnover and firm performance stronger when boards have incentives than when they do not. This finding suggests that providing explicit incentives to directors leads them to make better decisions. It is also consistent with the view that outside directors who receive incentive pay tend to have a professional rather than a personal relationship with the CEO and thus are relatively more independent.

The key issue in interpreting these studies is whether the relations they uncover are causal. In other words, do the particular attributes of the board, such as composition, size, or compensation directly affect the board's monitoring? If so, how can we observe firms with boards that are "too small" in equilibrium? Alternatively, do boards that are independent for other reasons tend to have certain characteristics? Ultimately, both effects probably explain some of the variation in the data. However, we place more weight on the noncausal explanation, since a board that is dominated by a CEO will not monitor regardless of its visible 
characteristics. On the other hand, a board made up of directors who wish to be independent of management will prefer to be paid with incentives and to arrange themselves, in terms of size and composition, in a way that best facilitates oversight of management.

\subsubsection{Evidence from the Takeover Market}

The active takeover market of recent years has provided a laboratory for studying the actions of boards, and for evaluating the relative merits of different kinds of directors. Shivdasani (1993) uses the takeover market as a means to study boards and their role in corporate governance. He estimates the probability that a firm is taken over by a hostile bidder during the takeover wave of the 1980s. This is a sensible approach because boards potentially affect takeover probabilities in two ways: First, boards can affect the quality of governance and, hence, influence the desirability of a firm as a target. Second, they can affect the takeover process itself, by controlling the ease with which a bidder can acquire the firm.

Arguably, Shivdasani's most interesting finding is that when outside directors have more additional directorships, it is less likely that the firm will be acquired in a hostile takeover. There are three potential interpretations of this finding. Higher quality directors could do a better job and, hence, be asked to be on more boards. In addition, by doing a good job as directors, they decrease the likelihood that the firms of which they are directors become takeover targets. Alternatively, directors in higher demand will turn down directorship opportunities at poorly managed firms, which are more prone to being acquired. A third, less charitable, interpretation is that outside directors who hold many directorships do so because they have established a reputation for supporting management and not "rocking the boat." A firm in which the directors are likely to support management is a less desirable target for hostile bidders (since it means a tougher fight) and less likely to agree to be acquired by a bidder not supported by management. 
In addition, Shivdasani finds that board ownership appears to affect the process of taking over a firm. Higher ownership by management and affiliated blockholders decreases the probability of a hostile bid while higher ownership by blockholders not affiliated with management increases it. Overall, the paper suggests that boards affect takeover probabilities by influencing both the quality of the company's management and the process of a takeover.

Complementary to Shivdasani (1993) is Cotter, Shivdasani, and Zenner (1997), which analyzes the effect of governance on the cross-sectional distribution of target firms' abnormal return during the tender-offer process. Cotter et al. find that when a target's board contains a majority of outside directors, the target receives about a 20-percentage-point higher return than a similar firm without a majority of outside directors on their board. This finding suggests that, conditional on being acquired, outside directors do a better job of negotiating on behalf of shareholders than do insiders. Together, the two papers suggest that the board composition of a potential target is an important factor in the takeover process.

Understanding the reaction of boards to takeover bids ultimately requires understanding the incentives of the directors. Harford (2000) documents that directors, in particular outside directors, have pecuniary incentives to resist the takeover bid. Following an acquisition, target directors generally lose their seats on the board and the associated directorship incomes. Harford finds that they make up some of the financial loss through gains on equity they hold in the firm. However, on average, the gain on the equity is too small to compensate the directors for the loss of directorship income. Therefore, Harford concludes that at the margin, financial considerations will lead outside directors in the direction of resisting possible acquisitions that are in the shareholders' interest. 
Byrd and Hickman (1992) analyze the role of boards of acquiring companies. They measure the stock price reaction to these firms when they announce an acquisition. Across all firms, they find an average abnormal drop in the acquirer's stock price of $1.33 \%$ over the two days surrounding the announcement of the acquisition. Byrd and Hickman then split the sample depending on whether the firms have boards with more than $50 \%$ independent directors. The sub-sample of firms in which at least $50 \%$ of the directors are independent exhibit a very small stock-price drop of $0.07 \%$, while the other sub-sample, containing a minority of independent directors, have a larger stock-price fall of $1.86 \%$. These two abnormal returns are significantly different from each other at the five-percent significance level. This finding indicates that the market perceives firms with independent boards as making better acquisitions (or at least less bad ones).

\subsubsection{Poison Pills}

Brickley et al. (1994) analyze the impact of the board on the decision to adopt a poison pill. This decision is interesting because a poison pill's impact on firm value is ambiguous from a theoretical perspective; pills serve to protect current management from a potentially valueimproving takeover, but increase shareholders' bargaining position in the face of a potential takeover. Brickley et al. find that the stock-market reaction to poison pills is positive when the board has a majority of independent directors and negative when it does not. This finding is consistent with the view that firms with a majority of outside directors adopt pills to further shareholders' interests, while firms with insider-dominated boards use poison pills as a way of further entrenching management.

\subsubsection{Executive Compensation}


Another role of the board is to set and to oversee the firm's compensation policies. A view, prevalent since at least Berle and Means (1932), is that CEOs can exert control over their boards, and use this control to extract "excessive" levels of compensation. For example, Michael Eisner, the longtime CEO of Disney, was able to have his personal attorney appointed to the Disney board, and even got him a seat on the compensation committee [see Wall Street Journal, Feb. 2, 1997]. Not too surprisingly, Eisner has been one of the most highly compensated CEOs in recent years.

Core et al. (1999) study the relations among board composition, ownership structure, and CEO pay. Their results suggest that firms with weaker governance structures tend to pay their CEOs more. In particular, they find that CEO pay rises with the number of outsiders appointed by the CEO, the number of directors over age 69 , board size, and the number of "busy" directors, where busy is defined in terms of the number of additional directorships held by a director. In addition, both Core et al. (1999) and Hallock (1997) find that CEO pay increases when a board contains interlocking directors, who are more likely to be influenced by the CEO. Finally, Yermack (1996) finds that the pay-performance relation for CEOs decreases with board size, suggesting that small boards give CEOs larger incentives and force them to bear more risk than do large boards. This evidence suggests that CEOs' influence over their boards does result in higher pay.

\subsubsection{Summary}

Probably the most natural question to ask about boards of directors concerns the extent to which they affect a firm's profitability. As noted above, searching for this relationship is problematic, ex ante, as a matter of both theory and econometrics. Moreover, those studies seeking a relationship between firm profitability and the composition of the board (e.g., proportion of 
outsiders on the board) have failed to find one. Studies looking at the relationship between board size and firm profitability, however, have found a surprisingly robust negative relation between board size and firm profitability.

In this section, we have examined studies that look more directly at what boards do, and which ask whether what they do is affected by their characteristics. In contrast to performance studies, these studies that have focused on particular actions generally find that board characteristics are important. Both board composition and size appear to affect the quality of decisions on CEO replacement, responses to a hostile takeover, adoption of a poison pill, and the design of CEO compensation schemes.

It is not clear how to reconcile these findings. One possibility is that outside directors are effective in crisis situations, but that smaller boards tend to be more effective in advising firms in day-to-day managerial decisions. But, again, is this an out-of-equilibrium phenomenon or an equilibrium phenomenon? Alternatively, these could reflect complicated dynamics having to do with the endogeneity of boards—-boards themselves respond to their environments, so a third factor would be driving both a board's characteristics and the potential problems that it faces.

\subsection{Factors that Affect the Board's Makeup}

The final set of studies on public corporations has examined the factors affecting the composition of the board; i.e., equation (3) from the system described above. Knowing the factors that affect board composition is clearly an important step in understanding boards and their role in corporate governance.

Perhaps the most natural way to examine board composition is to look cross-sectionally at the firm-level factors associated with different kinds of boards. However, cross-sectional analysis of boards is limited because of endogeneity issues; any variable associated cross- 
sectionally to board composition is likely to be jointly determined with board composition.

Despite this issue, cross-sectional correlations appear to be robust across samples and have been reported by a number of papers, including Weisbach (1988), Hermalin and Weisbach (1988), and Denis and Sarin (1999). It appears that tightly-held firms, in which founders are still active and the CEO has a large ownership position, tend to have insider-dominated boards. In contrast, larger and older firms are more likely to have professional management with small ownership stakes, and outsider-dominated boards. ${ }^{9}$

\subsubsection{Board Dynamics}

Because of these endogeneity issues, work on the determinants of board composition has focused on the dynamics of composition. To do so, these papers measure the impact of changes in a firm's characteristics on subsequent changes in board composition. Looking at changes in this fashion minimizes the potential joint endogeneity problem because of timing considerations; all that is required to avoid simultaneous equations bias is that firm-level variables are not affected by subsequent changes to the board.

Hermalin and Weisbach (1988) take this approach and estimate the factors that lead to changes in corporate boards. They find that three kinds of factors are statistically related to changes in the board: First they find that poor firm performance increases the likelihood that inside directors leave and that outside directors join the board. Second, they find that the CEO succession process appears to be intertwined with the board selection process. When a CEO nears retirement, firms tend to add inside directors, who are potential candidates to be the next CEO. Just after a CEO change, inside directors tend to leave the board, consistent with the hypothesis that these directors are losing candidates to be CEO. Finally, Hermalin and Weisbach

\footnotetext{
${ }^{9}$ One cross-sectional study not subject to the endogeneity critique is Kroszner and Strahan (2000). They find that firms with stable firms with collateralizable assets are more likely to have bankers on their boards, potentially
} 
document that after a firm leaves a product market, inside directors tend to depart and outside directors tend to join the board.

Denis and Sarin (1999) confirm these findings on a much larger sample of firms from a non-overlapping time period. Denis and Sarin find that large changes in board composition tend to occur after abnormally poor performance and around the time of a CEO change. They also find that the dynamics of ownership structure and board structure appear to be related in an important way; the change in the fraction of outsiders is negatively related to the change in CEO ownership.

Gilson (1990) examines the effect of bankruptcy on corporate boards. He finds that following a bankruptcy or private restructuring, banks take an active role in the firm's governance, including appointing a number of directors. Kaplan and Minton (1994) and Morck and Nakamura (1999) perform related studies of Japanese companies and the role of banks in their governance. These papers find that following poor performance, banks take a more active role in the firms' governance, including appointing a number of directors to the board. These studies are consistent with the view that creditors play a role in governance, which increases when firm performance lags and debtholders' claims become more uncertain.

\subsubsection{Board Composition and the Power Struggle between the Board and the CEO}

Probably the most important factor determining a board's effectiveness is its independence from the CEO. The board's independence from the CEO's influence is the underlying factor in many discussions of boards and their relationship with management. However, this variable is fundamentally unobservable; this unobservability is an important reason why empirical work on boards of directors is a challenging topic. A number of recent 
papers have addressed the power struggle between the board and CEO empirically in creative ways.

Hallock $(1997,1999)$ examines board interlocks, which occur when a firm’s employee sits on another firm's board, and that firm's employee sits on the first firm's board. These employees are generally the CEO or another person high in management of their respective firms. Given this type of relationship, the potential for collusive behavior on the part of the "interlocked" directors is particularly high. Hallock documents that the prevalence of interlocking directorships is too high to be explained by random chance. In addition, he finds that CEOs with interlocking boards get paid more than otherwise similar CEOs. These findings are consistent with the view that interlocking directorships help to enable the CEO have some degree of control over his board.

Shivdasani and Yermack (1999) examine the extent to which the CEO is involved in the board-selection process. This is an interesting empirical exercise both because case-study evidence suggests that CEOs play an important role in selecting new board members (Mace, 1986, and Lorsch and MacIver, 1989), and because theoretical work implies that the role of the CEO in choosing directors can influence on the board's effectiveness (Hermalin and Weisbach, 1998). Shivdasani and Yermack construct a measure of CEO involvement in the selection process based on whether the board has a separate nominating committee, and conditional on such a committee existing, whether the CEO is on it. These authors find that this measure of CEO involvement decreases the firm's subsequent number of independent directors. Shivdasani and Yermack's results are consistent with the view that, at least in some firms, the CEO is able to use his control over the selection process to decrease the board's independence. 
Baker and Gompers (2000) examine the board-selection process in a large sample of initial public offerings. They test whether factors that are plausibly related to CEO bargaining power influence the selection of board members. In particular, they argue that CEO tenure and CEO voting stake, as measured by its Shapley Value, are likely to be positively related to CEO bargaining power. In contrast, the presence of a venture capital investor, especially one with a strong reputation, is likely to decrease the CEO's bargaining power relative to the board. Empirically, Baker and Gompers find that, consistent with the bargaining framework, CEO tenure and CEO Shapley value are positively related to the number of insiders on the board, while the number of insiders decreases with the reputation of the venture capitalist financing the firm.

Overall, the literature has documented a number of facts about board dynamics. These facts can be explained reasonably well by a bargaining framework such as Hermalin and Weisbach (1998). Interested parties' control of the board appears to be a function of their bargaining power. When banks' financial claims become more uncertain and their legal rights in bankruptcy courts therefore stronger, their representation on boards increases (Gilson, 1990; Kaplan and Minton, 1994; and Morck and Nakamura, 1999). After a period of good performance, when a CEO's perceived value relative to a potential replacement is likely to be high, he is able to add more insiders to the board (Hermalin and Weisbach, 1988, and Denis and Sarin, 1999). Finally, direct measures of a CEO's bargaining position, such as his representation on the nominating committee, his voting stake, and his dealings with venture capitalists appear to affect board composition in ways consistent with the bargaining framework (Shivdasani and Yermack, 1999, Baker and Gompers, 2000).

\subsection{Studies of Boards Focusing on Particular Industries}


Most of the literature on boards of directors has relied on samples of public, industrial companies. This focus is natural given the visibility and importance of such companies. However, the diversity of firms in such studies adds heterogeneity, and potential noise to the issues being addressed. A number of studies have avoided this problem by focusing on one particular industry, or organizational form. This subsection surveys this work, and its implications for governance more broadly.

\subsubsection{The Money-Management Industry}

Two recent papers have examined boards of directors in the money-management industry. Tufano and Sevick (1997) consider a sample of open-end mutual funds while Dann et al. (2000) examine the role of the board in closed-end investment companies. Open-end and closed-end funds differ organizationally, but both types of organizations seek to maximize their funds' returns. Clearly, maximizing returns implies negotiating as good a deal as possible with the portfolio managers. Both Tufano and Sevick, and Dann et al. use this logic to focus on the relation between boards and expense ratios. Both papers find that when boards are made up of independent directors, fees tend to be lower. Both papers also find that expenses are increasing in board size. These results are consistent with the literature on industrial corporations suggesting that board size and composition are correlated with the board's effectiveness.

\subsubsection{Organizations with Prohibitions on Takeovers}

Two studies have used organizational restrictions on takeovers as a way of examining whether boards substitute for an external control market. Brickley and James (1987) construct a sample of banks, some of which are allowed by state law to be taken over, and some of which are from states that prohibit acquisitions of banks. Mayers et al. (1997) compare stock and mutual insurance companies for the same reason, since stock companies can be acquired but mutuals 
cannot. Each of the papers measures the impact of these regulatory requirements on board composition; the idea is to test whether internal and external control mechanisms are substitutes. The two papers find conflicting results: Brickley and James find that banks from states with takeover restrictions have fewer outside directors than banks from other states (contrary to the substitution hypothesis) and Mayers et al. find that mutual insurance companies employ more outside directors than stock insurance companies (consistent with the substitution hypothesis).

\subsubsection{Hospitals}

An important difference between for-profit firms and other organizations is in the organization's objective function. For-profit firms attempt to maximize the present value of economic profits; in contrast, a nonprofit's objective function is an endogenous choice not clearly specified by economic theory. This difference has implications for governance: While the governance of a for-profit aids in the goal of profit maximization, governance in a nonprofit must both choose the objective function and decide how best to maximize it.

Understanding these issues in nonprofit governance in general seems like an important topic for both economic theorists and empiricists. Two papers, Brickley and Van Horn (2000) and Eldenburg et al. (2000), have taken a first step in this direction, using samples of hospitals. Hospitals are a useful setting for studying the relation between organizational form and governance because they exist simultaneously as different types of organizations but perform the same basic services.

Brickley and Van Horn (2000) estimate the relation between CEO turnover and hospital performance and between CEO pay and hospital performance, on samples of for-profit and nonprofit hospitals. They find that both relations are similar on the for-profit and nonprofit hospitals and cannot reject the hypothesis that nonprofit and for-profit hospitals maximize the 
same objective function. Eldenburg et al.(2000) perform a similar experiment, looking at CEO and board turnover across a number of classes of hospitals, including for-profit, nonprofit, government and religious. Eldenburg et al. find that both board turnover and CEO turnover increase with poor hospital performance, high administrative costs, and high levels of uncompensated care. The sensitivity of turnover to these factors varies across hospital types. These findings are consistent with the view that different types of hospitals maximize different objective functions.

\section{Conclusions}

Boards of directors are an important element of governance systems, in both corporate and noncorporate organizations. Much research has been conducted on boards in the economics and finance fields. We have surveyed this research and its implications for governance.

Boards of directors are an institution that has arisen endogenously in response to the agency problems inherent in governing any organization. Formal theory on boards of directors has been quite limited to this point. Instead, the literature has developed as a series of empirical studies, which are generally aimed at addressing one of three questions:

1) How are board characteristics such as composition or size related to profitability?

2) How do board characteristics affect the observable actions of the board?

3) What factors affect the makeup of boards and how they evolve over time?

The primary findings from the empirical literature on boards are: Board composition is not related to corporate performance, while board size is negatively related to corporate performance. Both board composition and size do appear to be related to the quality of the board's decisions regarding CEO replacement, acquisitions, poison pills, and executive 
compensation. Finally, boards appear to evolve over time as a function of the relative bargaining position of the CEO relative to the existing directors. Firm performance, CEO turnover, and changes in ownership structure appear to be important factors affecting changes to boards.

Most research on boards begins with the assumption that directors' effectiveness is a function of the board's independence from management. The unobservability of the board's independence, together with endogeneity issues, thus makes empirical work on boards of directors a challenging topic: firstly, because of the econometric issues raised; and, secondly, because of the resulting difficulties of interpretation. Two characteristics of boards, their size and composition, are conceivably correlated with a board's independence. A number of studies have found that these characteristics are associated with boards that take better actions from the shareholders' perspective. However, lacking an adequate interpretation of these results—are they equilibrium or out-of-equilibrium results-we are reluctant to recommend policy changes on the basis of these studies.

All of this highlights the importance of better modeling of boards and their functions. This, however, is a difficult task. First, there is an important dynamic element to the board-CEO relationship that is missing from most principal-agent models: In this relationship, the “principal's" preferences change over time because changes in board membership mean the board becomes more or less favorably disposed to the CEO (among other possible changes in preferences). A second, and related, issue is that unlike standard agency models, the agent has some say over who his principal is. These aspects of the board-CEO relationship complicate the modeling problem in ways that have yet to be resolved.

Even were one to resolve these modeling issues, one would still be open to the complaint that the board is being modeled as a monolithic entity. In reality, a board consists of individuals 
who are unlikely to share a common agenda on all matters. For instance, after a proxy fight, directors hostile to management are sometimes added to a board that is otherwise friendly with management. But less dramatic and more common examples also exist: Because each board member bears $100 \%$ of the cost of her effort to monitor the CEO while enjoying only a fraction of the benefit, we should expect a free-rider problem among the directors. In addition, a CEO can potentially act strategically by playing one group of directors against another group.

Addressing these sorts of issues requires modeling of the board's inner workings. But once we treat the board as consisting of individuals, we face tremendous problems in applying our standard game-theoretic modeling strategies to the problem. Nor are we even assured that these are the appropriate modeling strategies: Experimental and other evidence is increasingly casting doubt on the appropriateness of game theory to explain the behavior of small groups of individuals, because individuals appear to value issues of emotions, fairness, and norm adherence more than economics tells us that they should. When these issues are addressed, we will have a more coherent model of the board and a better understanding of its role in governance.

Thus, while significant progress has been made in the last 15 years, there is much more to be done. To this point, the literature has documented a number of facts and empirical relations, most of which are for large, publicly traded companies. Formal theory has been limited, in large part because of the modeling issues involved. We expect that in the near future, research on boards will proceed in three main directions:

a) Modeling of inner workings of the board.

b) Tests of the implications of particular models rather than the "Are Outside Directors Good or Bad?" study that we have seen so much of to this point.

c) Studying boards of organizations other than large-publicly traded corporations. Of particular importance are small entrepreneurial firms and nonprofit organizations. 
We note that a number of the recent papers surveyed above have followed one or more of these approaches. It is likely that subsequent work along these lines will add much to our understanding of boards, and of governance in general. 


\section{References}

Agrawal, Anup and Charles Knoeber (2001) “Do Some Outside Directors Play a Political Role?" Journal of Law and Economics, forthcoming.

Almazan, Andres and Javier Suarez (2000) “Optimal Corporate Governance Structures,” Working Paper, University of Texas.

American Law Institute (1982) Principles of Corporate Governance and Structure: Restatement and Recommendations. American Law Institute, Tentative Draft No. 1.

Baker, M. and P. Gompers (2000) "The Determinants of Board Structure and Function in Entrepreneurial Firms," Working Paper, Harvard Business School.

Barro, J. and R. Barro (1990) "Pay, Performance and Turnover of Bank CEOs," Journal of Labor Economics, 8, pp. 448-481.

Baysinger, B. and H. Butler (1985) "Corporate Governance and the Board of Directors: Performance Effects of Changes in Board Composition," Journal of Law, Economics, and Organizations, 1, pp. 10124.

Berle, A. and G. Means. (1932) The Modern Corporation and Private Property. New York: MacMillan.

Bhagat, S. and B. Black (1999) "The Uncertain Relationship between Board Composition and Firm Performance," Business Lawyer, 54, pp. 921-963.

— and — (2000) "Board Independence and Long-Term Firm Performance," Working Paper, University of Colorado.

Blackwell, D., J. Brickley, and M. Weisbach (1994) "Accounting Information and Internal Performance Evaluation: Evidence from Texas Banks," Journal of Accounting and Economics, 17, pp. 331-358.

Borokhovich, K., R. Parrino, and T. Trapani, (1996) "Outside Directors and CEO Selection," Journal of Financial and Quantitative Analysis, 31, pp. 337-355.

Brickley, J., J. Coles, and R. Terry (1994) "Outside Directors and the Adoption of Poison Pills," Journal of Financial Economics, 35, pp. 371-390.

and C. James (1987) "The Takeover Market, Corporate Board Composition, and Ownership

Structure," Journal of Law and Economics, 30, pp. 161-180.

— and R. L. Van Horn (2000) "Incentives in Nonprofit Organizations: Evidence from Hospitals," Working Paper, University of Rochester.

Byrd, J. and K. Hickman (1992) "Do Outside Directors Monitor Managers? Evidence from Tender Offer Bids," Journal of Financial Economics, 32, pp. 195-207.

Carleton, W., J. Nelson, and M. Weisbach (1998) "The Influence of Institutions on Corporate Governance Through Private Negotiations: Evidence from TIAA-CREF,” Journal of Finance, 53, pp. 1335-1362. 
Core, J., R. Holthausen, and D. Larcker (1999) "Corporate Governance, Chief Executive Officer Compensation, and Firm Performance," Journal of Financial Economics, 51, pp. 371-406.

Cotter, J., A. Shivdasani, and M. Zenner (1997) "Do Independent Directors Enhance Target Shareholder Wealth during Tender Offers?” Journal of Financial Economics, 43, pp. 195-218.

Coughlan, A. and R. Schmidt (1985) "Executive Compensation, Managerial Turnover, and Firm Performance: An Empirical Investigation," Journal of Accounting and Economics, 7, 43-66.

Dann, L., D. Del Guercio, and M. Partch (2000) "Governance and Boards of Directors in Closed-End Investment Companies," Working Paper, University of Oregon.

Denis, D. and D. Denis (1995) "Performance Changes Following Top Management Dismissals," Journal of Finance, 50, pp. 1029-1055.

— and A. Sarin (1999) "Ownership and board structures in publicly traded corporations," Journal of Financial Economics, 52, pp. 187-224.

Eisenberg, T., S. Sundgren, and M. Wells (1998) "Larger Board Size and Decreasing Firm Value in Small Firms," Journal of Financial Economics, 48, pp. 35-54.

Eldenburg, L., B. Hermalin, M. Weisbach, and M. Wosinska (2000) "Hospital Governance, Performance Objectives, and Organizational Form," Working Paper, University of Illinois.

Fama, E. (1980) “Agency Problems and the Theory of the Firm," Journal of Political Economy, 88, pp. 288-307.

Fama, E. and M. Jensen (1983) "Separation of Ownership and Control," Journal of Law and Economics, 26, pp. 301-325.

Farrell, Kathleen, and David Whidbee (2000) "The Consequences of Forced CEO Succession for Outside Directors," Journal of Business, forthcoming.

Gertner, R. and S. Kaplan (1996) “The Value-Maximizing Board,” Working Paper, University of Chicago.

Gilson, S. (1990) "Bankruptcy, Boards, Banks, and Blockholders," Journal of Financial Economics, 27, 355-387.

Hallock, K. (1997) "Reciprocally Interlocking Boards of Directors and Executive Compensation," Journal of Financial and Quantitative Analysis, 32, 331-334.

Hallock, K. (1999) "Dual agency: Corporate Boards with reciprocally Interlocking Relationships," Executive Compensation and Shareholder Value, J. Carpenter and D. Yermack ed., pp. 55-75, Kluwer Academic Publishers.

Harford, J. (2000) “Takeover Bids and Target Directors' Incentives: Retention, Expertise, and SettlingUp," Working Paper, University of Oregon.

Hermalin, B. (1994) "Heterogeneity in Organizational Form: Why Otherwise Identical Firms Choose Different Incentives for their Managers," The RAND Journal of Economics, 25, pp. 518-537. 
and M. Katz (1993) "Judicial Modification of Contracts between Sophisticated Parties: A More Complete View of Incomplete Contracts and their Breach," The Journal of Law, Economics, and Organization, 9, pp. 230-255.

— and N. Wallace (1998) "Firm Performance and Executive Compensation in the Savings and Loan Industry," Working Paper, Walter A. Haas School of Business, University of California, Berkeley.

— and M. Weisbach (1988) "The Determinants of Board Composition," The RAND Journal of Economics, 19 (4), pp. 589-606.

— and — (1991) "The Effects of Board Composition and Direct Incentives on Firm Performance," Financial Management, 20 (4), pp. 101-12.

— and - (1998) "Endogenously Chosen Boards of Directors and their Monitoring of the CEO," American Economic Review, 88, pp. 96-118.

Hirshleifer, David, and Anjan Thakor (1994) "Managerial Performance, Boards of Directors, and Takeover Bidding," Journal of Corporate Finance, 1, pp. 63-90.

Holmstrom, B. (1999) "Managerial Incentive Problems: A Dynamic Perspective," Review of Economic Studies, 66(1), pp. 169-182.

Huson, M., R. Parrino, and L. Starks (2000) "Internal Monitoring and CEO Turnover: A Long-Term Perspective," Working Paper, University of Texas.

Jensen, M. (1993) "The Modern Industrial Revolution, Exit, and the Failure of Internal Control Systems," Journal of Finance, 48 (3), pp. 831-80.

— and K. Murphy (1990) "Performance Pay and Top-Management Incentives," Journal of Political Economy, 98, pp. 225-264.

Kaplan, S. (1994) "Top Executive Rewards and Firm Performance: A Comparison of Japan and the U.S.," Journal of Political Economy, 102, pp. 510-546.

Kaplan, S. and B. Minton (1994) "Appointments of Outsiders to Japanese Boards: Determinants and Implications for Managers," Journal of Financial Economics, 36, 225-258.

Kaplan, S. and D. Reishus (1990) "Outside Directorships and Corporate Performance," Journal of Financial Economics, 27, 389-410.

Karpoff, J. (1998) "Impact of Shareholder Activism on Target Companies: A Survey of Empirical Findings," Working Paper, University of Washington.

Klein, A. (1998) "Firm Performance and Board Committee Structure," Journal of Law and Economics, 41, pp. 275-299.

Kole, S. (1997) "The Complexity of Compensation Contracts", Journal of Financial Economics, 43, pp. 79-104. 
Kosnik, R. (1990) "Effects of Board Demography and Directors' Incentives on Corporate Greenmail Decisions," Academy of Management Journal, 33, pp. 129-150.

Kroszner, Randall, and Philip Strahan (2000) "Bankers on Boards: Monitoring, Conflicts of Interest, and Lender Liability," Journal of Financial Economics, forthcoming.

Lipton, Martin and Jay Lorsch (1992) “A Modest Proposal for Improved Corporate Governance," Business Lawyer, 48 (1), pp. 59-77.

Lorsch, Jay and Elizabeth MacIver (1989) Pawns or Potentates: The Reality of America's Corporate Boards, Harvard Business School Press: Boston.

MacAvoy, P., S. Cantor, J. Dana, and S. Peck (1983) "ALI Proposals for Increased Control of the Corporation by the Board of Directors: An Economic Analysis," in Statement of the Business Roundtable on the American Law Institute's Proposed 'Principles of Corporate Governance and Structure:

Restatement and Recommendation.' New York: Business Roundtable.

Mace, M. (1986) Directors: Myth and Reality, Boston: Harvard Business School Press.

Mayers, David, Anil Shivdasani, and Clifford Smith (1997) "Board Composition and Corporate Control, Evidence from the Insurance Industry," Journal of Business, 70.

Mehran, Hamid (1995) "Executive Compensation Structure, Ownership, and Firm Performance," Journal of Financial Economics, 38, pp. 163-184.

Meissner, C. (2000) "Mechanisms of Integrity: $19^{\text {th }}$ Century New England Banks and the Success of Connected Lending," Working paper, University of California at Berkeley.

Morck, Randall and Masao. Nakamura (1999) "Banks and Corporate Control in Japan," Journal of Finance, 54, pp. 319-340.

Morck, Randall, Andrei Shleifer, and Robert Vishny (1988) "Management Ownership and Market Valuation: An Empirical Analysis," Journal of Financial Economics, 20, pp. 293-316.

Perry, T. (2000) "Incentive Compensation for Outside Directors and CEO Turnover," Working paper, Arizona State University.

Rediker, K. and A. Seth (1995) "Boards of Directors and Substitution effects of Alternative Governance Mechanisms," Strategic Management Journal, 16, pp. 85-99.

Roe, M. (1994) Strong Manager, Weak Owners: The Political Roots of American Corporate Finance, Princeton University Press: Princeton, N.J.

Rosenstein, S. and J. Wyatt (1990) "Outside Directors, Board Independence, and Shareholder Wealth," Journal of Financial Economics, 26, pp. 175-184.

— and - (1997) "Inside Directors, Board Effectiveness, and Shareholder Wealth," Journal of Financial Economics, 44, pp. 229-248.

Shivdasani, Anil (1993) "Board Composition, Ownership Structure, and Hostile Takeovers,"Journal of Accounting and Economics, 16 (1/2/3), pp. 167-98. 
and David Yermack (1999) "CEO Involvement in the Selection of New Board Members: An Empirical Analysis,” Journal of Finance, 54, pp. 1829-1854.

Shleifer, A. and R. Vishny (1986) "Large Shareholders and Corporate Control," Journal of Political Economy, 94, pp. 461-488.

Shleifer, A. and R. Vishny (1997) “A Survey of Corporate Governance,” Journal of Finance, 52, pp. 737784.

Smith, Adam (1776) An Inquiry into the Nature and Cases of The Wealth of Nations. The Modern Library: New York.

Tufano, P. and Matthew Sevick (1997) "Board Structure and Fee-Setting in the U.S. Mutual Fund Industry," Journal of Financial Economics, 46, pp. 321-356.

Vancil, R. (1987) Passing the baton: Managing the Process of CEO Succession, Harvard Business School Press: Boston.

Warner, J., R. Watts, and K. Wruck (1988) "Stock Prices and Top-Management Changes," Journal of Financial Economics, 20, pp. 461-492.

Warther, Vincent (1998) "Board Effectiveness and Board Dissent: A Model of the Board's Relationship to Management and Shareholders," Journal of Corporate Finance.

Weisbach, Michael (1988) "Outside Directors and CEO Turnover," Journal of Financial Economics, 20, pp. 431-60.

Wu, Yilin (2000) “Honey, I Shrunk the Board,” Working Paper, University of Chicago.

Yermack, D. (1996) "Higher Valuation of Companies with a Small Board of Directors," Journal of Financial Economics, 40, pp. 185-212.

Zajac, E. and J. Westphal (1994) "The Costs and Benefits of Managerial Incentives and Monitoring in Large U.S. Corporations: When is More not Better?" Strategic Management Journal, 15, pp. 121-142. 